\title{
Pleckstrin homology domain of phospholipase C- $\gamma 1$ directly binds to 68-kDa neurofilament light chain
}

\author{
Sung-Kuk Kim ${ }^{1}$, Jang Hyun $\mathrm{Choi}^{2}$, \\ Pann-Ghill Suh ${ }^{2}$ and Jong-Soo Chang ${ }^{1,3}$ \\ ${ }^{1}$ Department of Life Science \\ College of Natural Science \\ Daejin University \\ Kyeonggido 487-711, Korea \\ ${ }^{2}$ Department of Life Science \\ Division of Molecular and Life Science \\ Pohang University of Science and Technology (POSTECH) \\ Kyeongbuk 790-784, Korea \\ ${ }^{3}$ Corresponding author: Tel, 82-31-539-1853; \\ Fax, 82-31-539-1850; E-mail, jchang@daejin.ac.kr
}

\section{Accepted 23 May 2006}

Abbreviations: PLC, phospholipase C; NF, neurofilament; PH, pleckstrin homology; $\mathrm{PIP}_{2}$, phosphatidylinositol 4,5-bisphosphate; NGF, nerve growth factor; PC12, pheochromocytoma 12; RIPA, radioimmunoprecipitation assay

\footnotetext{
Abstract

Phosphoinositide-specific phospholipase C- $\gamma 1$ (PLC$\gamma 1)$ has two pleckstrin homology (PH) domains: an amino-terminal domain ( $\left.\mathrm{PH}_{1}\right)$ and a split $\mathrm{PH}$ domain (PH2). Here, we show that overlay assay of bovine brain tubulin pool with glutathione-S-transferase (GST)-PLC- $\gamma 1$ PH domain fusion proteins, followed by matrix-assisted laser-desorption ionization-time of flight mass spectrometry (MALDI-TOF MS), identified 68-kDa neurofilament light chain (NF-L) as a binding protein of amino-terminal $\mathrm{PH}$ domain of PLC- $\gamma 1$. NF- $L$ is known as a component of neuronal intermediate filaments, which are responsible for supporting the structure of myelinated axons in neuron. PLC- $\gamma 1$ and NF-L colocalized in the neurite in PC12 cells upon nerve growth factor stimulation. In vitro binding assay and immunoprecipitation analysis also showed a specific interaction of both proteins in differentiated PC12 cells. The phosphatidylinositol 4, 5-bisphosphate $\left[\mathrm{PI}(4,5) \mathrm{P}_{2}\right]$ hydrolyzing activity of PLC- $\gamma 1$ was slightly decreased in the presence of purified NF-L in vitro, suggesting that NF-L inhibits PLC- $\gamma 1$. Our results suggest that PLC- $\gamma 1$-associated NF-L sequesters the phospholipid from the PH domain of PLC- $\gamma 1$.
}

Keywords: neurofilament protein L; PC12 cells; phospholipase C gamma; phosphatidylinositol 4,5-diphosphate; protein interaction mapping

\section{Introduction}

PLC- $\gamma 1$ plays a pivotal role in cellular signaling. Activated PLC- $\gamma 1$ hydrolyzes phosphatidylinositol 4,5-bisphosphate $\left(\mathrm{PI}(4,5) \mathrm{P}_{2}\right)$ to produce inositol 1,4,5trisphosphate $\left(\mathrm{IP}_{3}\right)$ and diacylglycerol $(\mathrm{DG})$, which regulate the release of $\mathrm{Ca}^{2+}$ from intracellular stores and activate protein kinase $C(P K C)$, respectively (Berridge, 1993; Nishizuka, 1995). PLC- $\gamma 1$ has two pleckstrin homology $(\mathrm{PH})$ domains for proteinprotein and protein-lipid interactions: one $\mathrm{PH}$ domain $(\mathrm{PH} 1)$ is located in the $150 \mathrm{~N}$-terminal amino acid residues, the other $\left(\mathrm{PH}_{2}\right)$ is split by $\mathrm{SH} 2-\mathrm{SH} 2-\mathrm{SH} 3$ domain (Gibson et al., 1994). PH domains bind with high specificity and affinity to phosphoinositides such as PIP, $\mathrm{PIP}_{2}, \mathrm{PIP}_{3}$ and $\mathrm{IP}_{3}$ (Lemmon and Ferguson, 2000 ), and the $\mathrm{PH}$ domains of signaling molecules are often involved in targeted translocation of molecules to cell membranes (Lemmon et al., 1996; Falasca et al., 1998). So, it is critical to identify and characterize the factors that regulate the PLC- $\gamma 1$ activity by binding with $\mathrm{PH}$ domain of PLC- $\gamma 1$. Here, we identify neurofilament light chain (NF-L) that specifically associate with the PLC- $\gamma 1 \mathrm{PH}$ domain.

Neurofilaments (NF) are the most abundant cytoskeletal component in large myelinated axons during neuronal differentiation. They are heteropolymers composed of NF-L, NF-M and NF-H (Ching and Liem, 1993; Lee et al., 1993; Nakagawa et al., 1995). Each of them composed of three domains, an aminoterminal head domain, an $\alpha$-helix rich rod domain, and carboxy-terminal tail domains (Fuchs and Weber, 1994). In vitro reconstitution studies observed that NF-L assembles to form the core filaments (Hisanaga and Hirokawa, 1990) and the resulting core filaments provide a scaffold to form intact neurofilament via cross-bridges either with NF-M or NF-H (Fuchs and Weber, 1994; Nakagawa et al., 1995). Recently, it is revealed that the transgenic mice overexpressing NF-L or NF-H resulted in abnormal assembly and aggregation of neurofilaments in neuronal cell bodies (Cote et al., 1993; Xu et al., 1993). Such neurofilament accumulation has been associated with neurodegenerative diseases such as Charcot-Marie-Tooth disease (Watson et al., 1994; Fabrizini et al., 2004), 
Alzheimer's disease (Shepherd et al., 2002; Norgren et al., 2003) and amyotrophic lateral sclerosis (Hirano et al., 1984; Collard et al., 1995; Al-Chalabi and Miller, 2003).

Here, we present NF-L that specifically interact with the $\mathrm{PH}$ domain of PLC- $\gamma 1$, and showed that NF-L inhibits PLC- $\gamma 1$ activity by binding to $\mathrm{PH}$ domain of PLC- $\gamma 1$.

\section{Materials and Methods}

\section{Antibodies}

Monoclonal anti-NF-L (mAb 1615) and polyclonal anti-NF-L were purchased from Chemicon (Temecula, $\mathrm{CA})$. The horseradish peroxidase (HRP)-conjugated goat anti-mouse and goat anti-rabbit antibodies were purchased from Upstate Inc. (Lake Placid, NY). Monoclonal anti-FLAG M5, polyclonal anti-PLC- $\gamma 1$ and highly purified NF-L from bovine spinal cord were obtained from Sigma-Aldrich (St. Louis, Mo). Fluorescein- conjugated Affinipure goat anti-rabbit IgG and rhodamine-conjugated Affinipure goat antimouse IgG were from Jackson ImmunoResearch Laboratories (West Grove, PA).

\section{In vitro binding assay with GST fusion proteins}

Using rat PLC- $\gamma 1$ cDNA (Suh et al., 1988) as a template, glutathione-s-transferase (GST) constructs for fusion proteins were generated by polymerase chain reaction (PCR) as previously described (Chang et al., 2002). GST fusion proteins were expressed in E.coli and incubated the lysates with glutathione sepharose (GSH) bead, and then washed extensively with Igepal buffer $(20 \mathrm{mM}$ Tris- $\mathrm{Cl}, \mathrm{pH}$ 7.5, $1 \%$ Igepal CA-630, $300 \mathrm{mM} \mathrm{NaCl}, 2 \mathrm{mM} \mathrm{MgCl} 2$, $1 \mathrm{mM}$ EDTA, $10 \mu \mathrm{g} / \mathrm{ml}$ aprotinin, $10 \mu \mathrm{g} / \mathrm{ml}$ leupeptin, $1 \mathrm{mM}$ phenylmethylsulfonyl fluoride (PMSF) and 1 $\mathrm{mM}$ sodium orthovanadate), resolved by $10 \%$ SDSpolyacrylamide gel electrophoresis (PAGE), and then transferred to polyvinylidene difluoride (PVDF) membranes. The membrane- bound proteins were detected with enhanced chemiluminescence (ECL) detection system (Amersham Biosciences, Toroed, Norway) using monoclonal anti-FLAG and HRPconjugated goat anti-mouse antibodies.

\section{DNA construction and expression}

For the expression in $E$. coli, cDNA sequence encoding the amino-terminal $\mathrm{PH}$ domain $(\mathrm{PH} 1)$ of rat PLC- $\gamma 1$ (amino acids 25-145) (Suh et al., 1988) was ligated into the pGEX-5X-1 vector (Amersham Pharmacia Biotech, Piscatawan, NJ) for GST-PH1 fusion protein expression, as described previously (Chang et al., 2005). PCR-amplified rat cDNAs encoding NF-L (purchased from the American Type Culture Collection, ATCC, Rockville, MD) were ligated into the EcoRI/Sal I restriction site of pGEX$5 X-1$. For the expression of domain-specific NF-L fusion proteins, PCR-amplified cDNAs for the NF-L head domain (NF-L(H), amino acid residues 1-93), rod domain (NF-L(R), amino acid residues 93-397), head/rod domain (NF-L(H/R), amino acid residues 1-397), and tail domain (NF- L(T), amino acid residues 398-542) were separately inserted into the EcoRI/Sal I sites of pGEX-5X-1. All constructs were prepared using the Quiagen Plasmid Maxi Kit (Quiagen Inc., Santa Clarita, CA) and confirmed by DNA sequencing of the ligation sites.

\section{Immunoprecipitation and immunoblotting}

PC12 cells treated with $50 \mathrm{ng} / \mathrm{ml}$ nerve growth factor (NGF) were washed twice with phosphate- buffered saline (PBS) and lysed with radio immunoprecipitation assay (RIPA) buffer $(20 \mathrm{mM}$ Tris, $\mathrm{pH}$ $7.2,1 \%$ Triton $\mathrm{X}-100,1 \%$ sodium deoxycholate, $0.1 \%$ SDS, $150 \mathrm{mM} \mathrm{NaCl}, 1 \mathrm{mM}$ sodium orthovanadate, $10 \mu \mathrm{g} / \mathrm{ml}$ leupeptin, $10 \mu \mathrm{g} / \mathrm{ml}$ aprotinin and $1 \mathrm{mM}$ PMSF). For agonist stimulation, cells were serum starved for $24 \mathrm{~h}$ and then stimulated with 50 $\mathrm{ng} / \mathrm{ml}$ NGF for $48 \mathrm{~h}$. The lysate supernatants were precleared by incubation with Pansorbin (Calbiochem, La Jolla, CA) for $30 \mathrm{~min}$. Precleared cell lysates were then incubated for $2 \mathrm{~h}$ with either polyclonal anti- NF-L antibodies or monoclonal anti-PLC$\gamma 1$ antibodies conjugated with affinity purified goat anti- mouse immunoglobulin G (IgG)-bound Pansorbin (Calbiochem). The immune complexes were collected by centrifugation, washed three times with ice-cold RIPA buffer, and then resolved by $10 \%$ SDS-PAGE and blotted to a PVDF membrane. The blot was probed with either anti-PLC- $\gamma 1$ or anti- NF-L antibody and the immunoreactive bands were visualized by ECL detection using HRP-conjugated goat anti-mouse lgG.

\section{Far Western blot analysis}

Purified bovine tubulin $(0.2 \mu \mathrm{g}$ per lane) was resolved in $10 \%$ SDS-PAGE and transferred onto PVDF membrane. Nonspecific binding to the membrane was blocked by adding $2 \%$ skim milk in Tris-buffered Tween 20 (TBT) for $1 \mathrm{~h}$ at room temperature. The membranes were then incubated with GST-PH1 and GST as a control $(0.5 \mu \mathrm{g} / \mathrm{ml})$ in blocking buffer for $14 \mathrm{~h}$ at $4^{\circ} \mathrm{C}$. After washes in TBT buffer, the membranes were incubated with anti-GST antibody for $2 \mathrm{~h}$ at room temperature. After washing the membrane with TBT buffer again, bound proteins were detected by successive incubation with HRPconjugated anti-goat antibody as a second antibody 
using ECL detection system.

\section{Immunofluorescent microscopy}

PC12 cells were seeded on glass coverslips in 6 -well plates, serum starved and treated $50 \mathrm{ng} / \mathrm{ml}$ NGF for 2 days in Dulbecco's modified Eagle's medium (DMEM) with 0.5\% FBS. The cells were fixed at $37^{\circ} \mathrm{C}$ for $10 \mathrm{~min}$ in $4 \%$ paraformaldehyde and then incubated with polyclonal anti-NF-L or monoclonal anti-PLC- $\gamma 1$ antibodies for $1 \mathrm{~h}$ at room temperature in a humidity chamber. Following complete washing with PBS, the cells were incubated with fluorescein-conjugated Affinipure goat anti-rabbit IgG or rhodamine-conjugated Affinipure goat antimouse IgG. Immunostained cells were observed with a fluorescent microscope (Nikon Eclipse E600 Epifluorescence Microscope) and the images were captured with a digital image microscope camera.

\section{Mass spectrometry}

Gel slices corresponding to the appropriate protein bands were crushed and destained by washing with $50 \%$ acetonitrile in $25 \mathrm{mM} \mathrm{NH}_{4} \mathrm{HCO}_{3}$. The gel slices were then incubated overnight with trypsin (Promega, Madison, WI) in $25 \mathrm{mM} \mathrm{NH}_{4} \mathrm{HCO}_{3}$ at $37^{\circ} \mathrm{C}$. The resulting peptides were eluted with matrix solution ( $5 \mathrm{mg} / \mathrm{ml} \alpha$-cyano-4-hydroxycinnamic acid, $0.1 \%$ trifluoroacetic acid and $50 \%$ acetonitrile) and applied to the MALDI target plate. Peptide molecular weights were measured on a MALDI-TOF mass spectrometer (Voyager-DE STR; Applied Biosystems, Inc., Foster City, CA). Peptide mass maps were searched against theoretically derived maps from proteins found in the nonredundant protein database (NCBI) using the ProFound online program (www.proteometrics.com).

\section{PLC- $\gamma 1$ activity assay}

PLC- $\gamma 1$ activity was measured as described previously (Hepler et al., 1993). Briefly, the substrate was prepared as sonicated vesicles of $75 \mathrm{mM} \mathrm{PIP}_{2}$, $75 \mathrm{mM}\left[{ }^{3} \mathrm{H}\right] \mathrm{PI}(4,5) \mathrm{P}_{2}(9,000-10,000 \mathrm{cpm} /$ assay $)$ and $750 \mathrm{mM}$ PE in $50 \mathrm{mM}$ HEPES buffer $(\mathrm{pH} 7.0)$. Reactions were performed for $20 \mathrm{~min}$ at $30^{\circ} \mathrm{C}$ in 100 $\mu$ final volume containing $100 \mathrm{ng}$ PLC- $\gamma 1$ and $2 \mathrm{mM}$ $\mathrm{Ca}^{2+}$, and terminated by addition of $1 \mathrm{ml}$ of chloroform/methanol/ $/ \mathrm{HCl}(50: 50: 0.5)$ and $400 \mu \mathrm{l}$ of $1 \mathrm{~N}$ $\mathrm{HCl}$. The mixtures were vortexed and centrifuged for $10 \mathrm{~min}$ at $2,000 \mathrm{rpm}$. The aqueous phase containing $\left[{ }^{3} \mathrm{H}\right] \quad \mathrm{IP}_{3}$ was collected and subjected to scintillation counting. The effect of NF-L on PLC- $\gamma 1$ activity was examined by adding appropriate amounts of purified neurofilament mixtures to the PLC- $\gamma 1$ assay mixture.

\section{Results}

The PH1 domain of PLC- $\gamma 1$ directly binds to NF-L In our previous studies aimed at understanding the
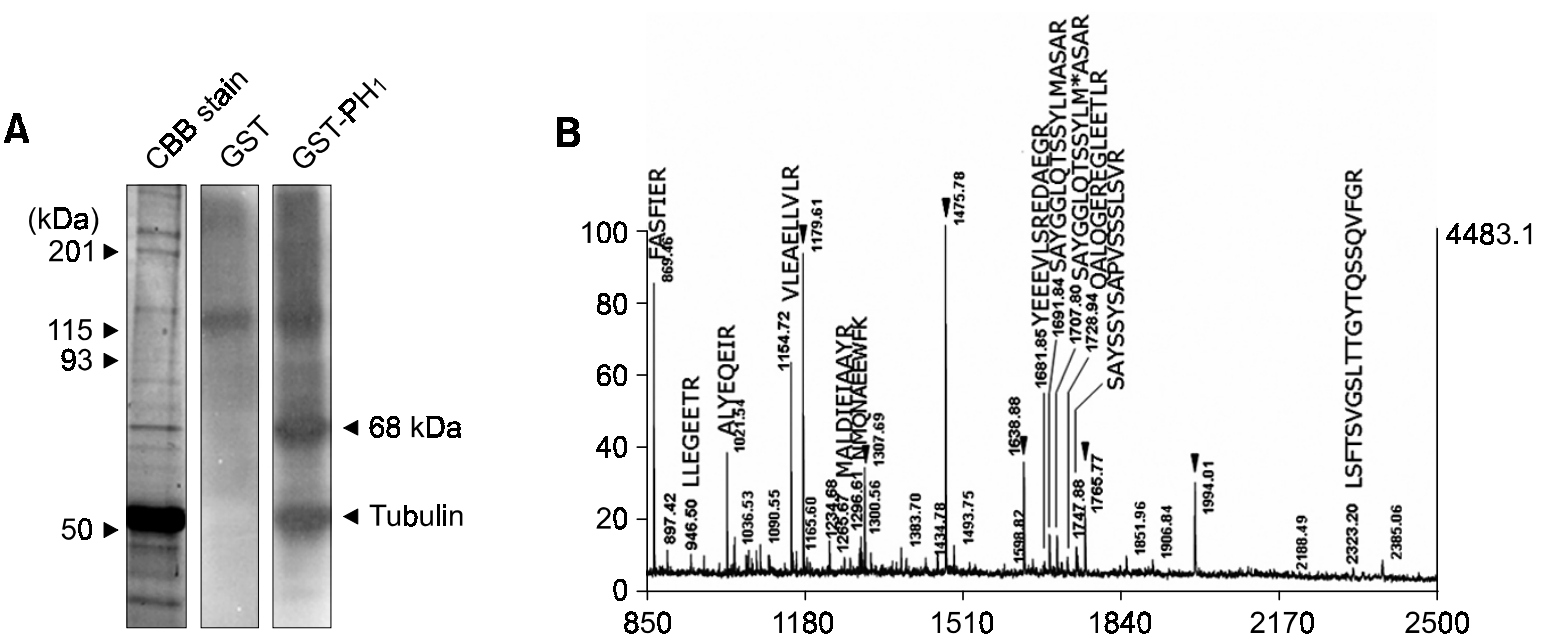

Figure 1. The PH domain of PLC-y1 directly binds to NF-L. (A) Far Western blot hybridization reveals a direct interaction between PLC- $\gamma 1$ and NF-L. Purified tubulin from bovine brain ( $2 \mu \mathrm{g}$ per lane) was resolved by $10 \%$ SDS-PAGE, and either stained with Coomassie Brilliant Blue (CBB) or transferred to a PVDF membrane, probed with purified GST and GST-PH 1 fusion proteins, and detected with an HRP-conjugated goat anti-GST antibody. (B) MALDI-TOF mass spectrometric analysis of tryptic peptides from the unidentified 68-kDa protein. Tryptic peptides for keratin and oxidized methionine are indicated by $\boldsymbol{\nabla}$ and *, respectively. 
Table 1. Tryptic peptides of NF-L identified by MALDI-TOF

\begin{tabular}{lccc}
\hline & & \multicolumn{2}{c}{$\begin{array}{c}\text { Monoisotopic mass } \\
\text { Peptide sequence }\end{array}$} \\
& & Start-end $^{\mathrm{b}}$ & \multicolumn{2}{c}{$\left.\left(\mathrm{H}^{+}\right]\right)$} \\
\cline { 3 - 4 } & & Theoretical & Experimental \\
\hline SAYSSYSAPVSSSLSVR & $37-53$ & 1747.8 & 1747.88 \\
FASFIER & $100-106$ & 868.9 & 869.46 \\
VLEAELLVLR & $116-125$ & 1154.4 & 1154.72 \\
ALYEQEIR & $136-143$ & 1021.1 & 1021.54 \\
QALQGEREGLEETLR & $157-171$ & 1728.8 & 1728.94 \\
YEEEVLSREDAEGR & $177-190$ & 1681.7 & 1681.85 \\
NMQNAEEWFK & $272-281$ & 1296.4 & 1296.61 \\
MALDIEIAAYR & $380-390$ & 1265.4 & 1265.67 \\
LLEGEETR & $392-399$ & 946.0 & 946.50 \\
LSFTSVGSLTTGYTQ- & $400-421$ & 2323.5 & 2323.20 \\
SSQVFGR & & & \\
\hline
\end{tabular}

${ }^{\mathrm{a}}$ Amino acid residues derived from the $68-\mathrm{kD}$ a protein.

${ }^{b}$ Position of the amino acid residue in the deduced peptide sequence of bovine NF-L.

relationship between $\beta$-tubulin and PLC- $\gamma 1$-dependent signaling (Chang et al., 2005), we detected a 68-kDa protein capable of specifically interacting with our GST-PLC- $\gamma 1-P H 1$ domain fusion protein in an overlay assay of purified bovine brain tubulin fraction (Figure 1A). In the present study, we focused on the interaction between the PH domain of PLC- $\gamma 1$ and the $68-\mathrm{kDa}$ protein. To identify this protein, we excised the gel band and analyzed it using MALDITOF mass spectrometry. Figure $1 \mathrm{~B}$ shows the mass spectrum derived from a tryptic digest of this $68-\mathrm{kDa}$ protein. Searching the peptide mass map against the NCBI protein database allowed us to identify the 68-kDa protein as bovine NF-L (Table 1). This identification was confirmed by Western blotting with monoclonal anti-NF-L (Figure 2).

As the bovine brain tubulin fraction contains NF-L, and PLC- $\gamma 1$ binds to both $\beta$-tubulin and NF-L, we examined the co-existence of these three proteins in the bovine brain fraction. Western blotting of purified bovine brain tubulin with specific antibodies revealed that all three proteins were present in the tubulin pool (Figure 2), suggesting that PLC- $\gamma 1$, tubulin and NF-L may exist as a trimeric complex in nerve cells. This is consistent with the results of microtubule (MT)/NF (Flynn and Purich, 1987; Hirokawa, 1982), MT/PLC- $\gamma 1$ (Chang et al., 2005) and NF/PLC- $\gamma 1$ interactions (in this study). Far Western blot analysis using a GST-PH1 fusion protein confirmed the interaction between PLC- $\gamma 1$ and NF-L (Figure 1A), suggesting that this may be a direct interaction. Also,

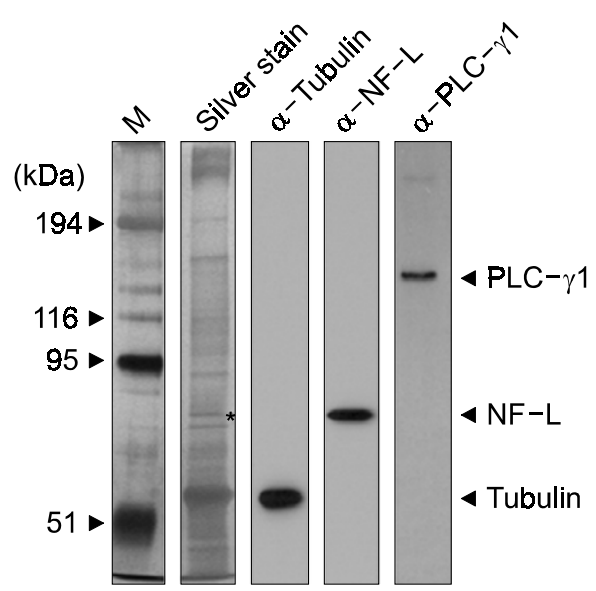

Figure 2. PLC- $\gamma 1$ formed a complex with microtubule (MT) and neurofilament (NF). Purified tubulin from bovine brain ( $2 \mu \mathrm{g}$ per lane) was resolved by $10 \%$ SDS-PAGE, transferred to a nylon membrane and probed with anti-tubulin, anti-NF-L or anti-PLC- $\gamma 1$ antibodies, followed by an HRP-conjugated goat anti-mouse antibody for detection. The position of the NF-L band (determined by silver staining) is indicated with an asterisk $\left({ }^{*}\right)$.

A
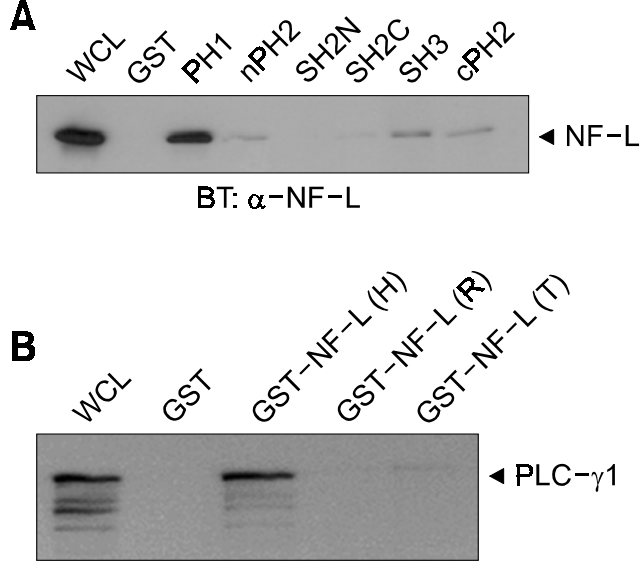

Figure 3. Domain specificity in PLC- $\gamma 1 / \mathrm{NF}-\mathrm{L}$ interactions. (A) To examine the domain specificity of the NF-L association, different GST fusion proteins were incubated with PC12 cell lysates containing NF-L proteins. The bound proteins were resolved by $10 \%$ SDS-PAGE and immunoblotted with an anti-NF-L antibody. (B) The NF-L head domain interacts with PLC- $\gamma 1$. The head $(H)$, rod $(R)$ and tail $(T)$ domain GST fusion proteins were incubated with $\mathrm{PC} 12$ cell lysates for $1 \mathrm{~h}$ at $4^{\circ} \mathrm{C}$, and the bound proteins were analyzed by Western blotting with anti-PLC-y1. WCL indicates the whole cell lysates used for each pull-down experiment.

we examined the binding specificity of the $\mathrm{PH}$ domains to NF-L by comparing the binding reactions of GST fusion proteins including GST-PH1, -nPH2, $-\mathrm{CPH} 2,-\mathrm{SH} 2$, and -SH3. As shown in Figure $3 \mathrm{~A}$, Western blotting revealed that only GST-PH1 strongly associated with NF-L, whereas GST-nPH2, - $\mathrm{CPH} 2$, 

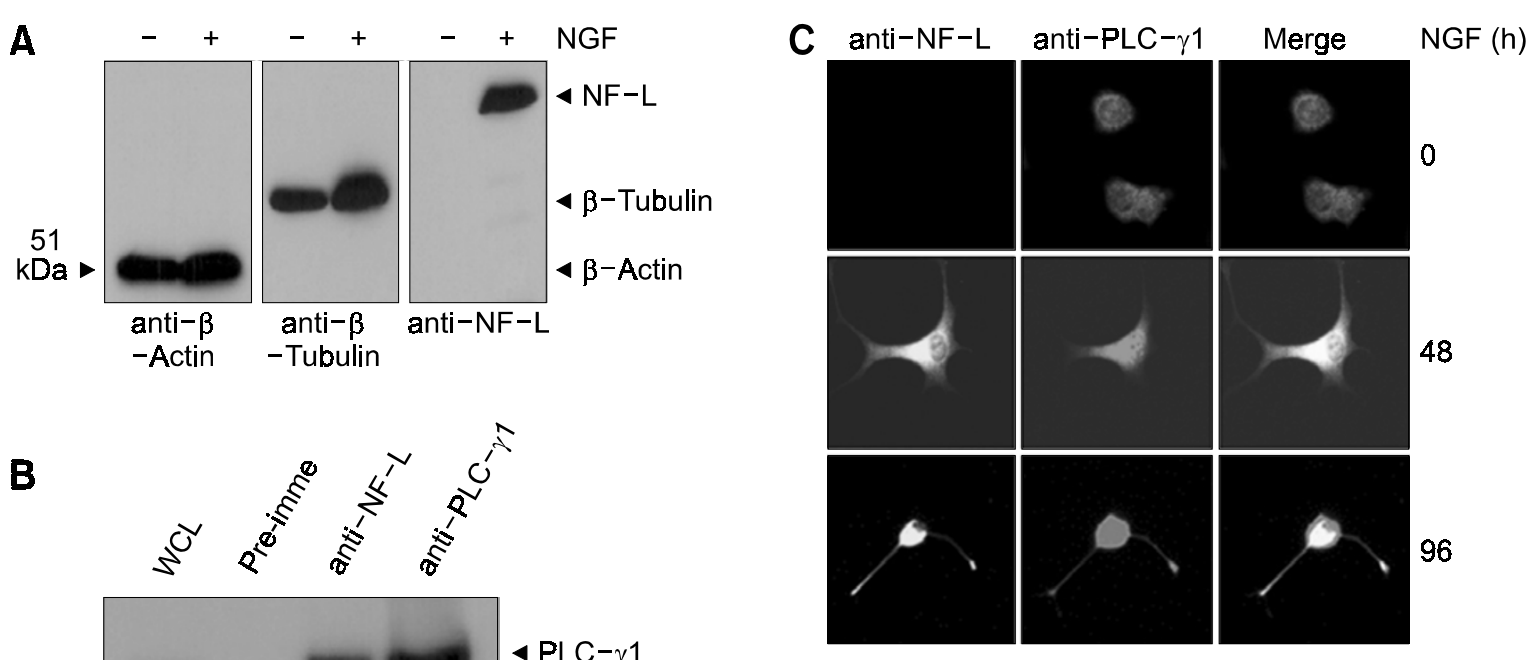

B

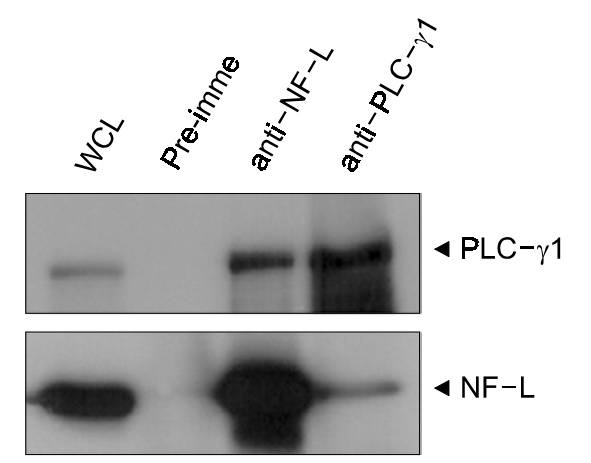

Figure 4. NGF-induced NF-L expressions in PC12 cells. (A) NF-L expression levels in PC12 cells treated with or without NGF (50 ng/ml) were examined by Western blotting. Serum-starved PC12 cells were treated with NGF for $48 \mathrm{~h}$ and then harvested for Western blotting with anti- $\beta$-actin, anti- $\beta$-tubulin and anti-NF-L. (B) Immunoprecipitation analysis of the in vivo interaction between NF-L and PLC- $\gamma 1$. PLC- $\gamma 1$ from differentiated PC12 cell lysates was coimmunoprecipitated with NF-L (upper), or NF-L was coimmunoprecipitated with PLC- $\gamma 1$ (lower), using polyclonal antibodies in both cases. WCL indicates the whole cell lysates used for immunoprecipitation. (C) Colocalization of PLC- $\gamma 1$ and NF-L in the neurite was assessed by double immunostaining for NF-L and PLC- $\gamma 1$. PC12 cells treated with or without NGF $(50 \mathrm{ng} / \mathrm{ml})$ for $48-96 \mathrm{~h}$ were fixed with $4 \%$ paraformaldehyde for $10 \mathrm{~min}$ at $37^{\circ} \mathrm{C}$ and stained with a monoclonal anti-PLC- $\gamma 1$ and a polyclonal anti-NF-L antibody, followed by rhodamine- and FITC-labeled secondary antibody staining, respectively.

\section{$-\mathrm{SH} 2 \mathrm{~N}, \mathrm{SH} 2 \mathrm{C}$ and $-\mathrm{SH} 3$ did not.}

Lastly, to identify the PLC- $\gamma 1 \mathrm{PH} 1$ domain binding site on NF-L, we performed in vitro binding assays with the various GST-NF-L fusion proteins. As shown in Figure 3B, PLC- $\gamma 1$ associated with GSTNF-L $(H)$, but not GST-NF-L (R) and GST-NF-L $(T)$, indicating that this binding occurs in the head domain of NF-L.

\section{NGF induces NF-L expression and formation of PLC- $\gamma$ 1/NF-L complexes in PC12 cells}

Rat pheochromocytoma PC12 cells differentiate into neuron-like cells in response to NGF treatment. To test the possible interaction of NF-L with PLC- $\gamma 1$ following NGF treatment, we examined the effects of agonist stimulation on coimmunoprecipitation of PLC$\gamma 1$ with NF-L in vivo. As shown in Figure 4B, PLC- $\gamma 1$ coimmunoprecipitated with NF-L and vice versa in NGF-treated PC12 cells, but not in untreated proliferating PC12 cells (data not shown). This might due to the lack of NF-L proteins in proliferating PC12 cell extracts, as shown by Western blotting (Figure $4 A)$.

To examine the subcellular localizations of PLC- $\gamma 1$ and NF-L in differentiated PC12 cells, we performed double immunostaining using anti-PLC- $\gamma 1$ and anti-NF-L antibodies. As shown in Figure 4C, PLC- $\gamma 1$ and NF-L were localized in neurite and cell bodies of differentiated PC12 cells. Overlays of the fluorescent microscopic images showed that the proteins dominantly colocalized in both locations. In contrast, untreated proliferating PC12 cells showed no NF-L immunostaining (Figure 4C).

\section{$\mathrm{PI}(4,5) \mathrm{P}_{2}$ promotes the association between NF-L and $\mathrm{PH} 1$ domain}

Because the $\mathrm{PH}$ domain is known to be a phosphoinositides binding motif in numerous proteins (Lemmon and Ferguson, 2000), we next examined whether phosphoinositides are involved with the molecular interaction between the PLC- $\gamma 1 \mathrm{PH}$ domain and NF-L. We performed a GST-PLC- $\gamma 1$ $\mathrm{PH}_{1}$ pull-down assay using $\mathrm{PC} 12$ cell lysates containing $\mathrm{Pl}(4,5) \mathrm{P}_{2}$ in vesicle form. As shown in Figure 5, substantially more NF-L proteins bound to the GST-PLC- $\gamma 1-\mathrm{PH} 1$ domain in the presence of $\mathrm{PI}(4,5) \mathrm{P}_{2}$, compared to $\mathrm{PI}(4,5) \mathrm{P}_{2}$-untreated controls. These findings indicate that $\mathrm{PI}(4,5) \mathrm{P}_{2}$ promotes the 


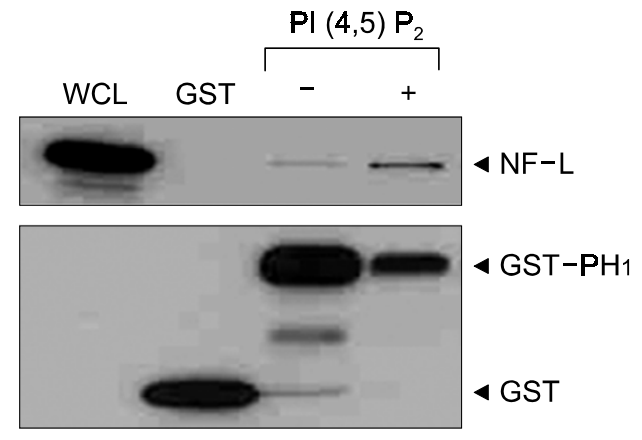

Figure 5. $\mathrm{PI}(4,5) \mathrm{P}_{2}$ promotes the interaction between the $\mathrm{PH}$ domain of PLC- $y 1$ and NF-L. GST-PH1 domain fusion proteins were incubated with NGF-treated PC12 cell extracts (NF-L pool) in the presence of $\mathrm{PI}(4,5) \mathrm{P}_{2}(5 \mu \mathrm{g} / 100 \mu \mathrm{l}$ reaction mixture), and bound proteins were analyzed by Western blotting with anti-NF-L (upper) and anti-GST (middle) antibodies. Two independent experiments showed similar results.

association of PLC- $\gamma 1$ with NF-L.

\section{NF-L inhibits PLC- $\gamma 1$ activity}

To examine whether the complex formation affects PLC- $\gamma 1$ activity, we measured the $\mathrm{PI}(4,5) \mathrm{P}_{2}$ hydrolyzing activity of PLC- $\gamma 1$ in the presence of purified $N F-L$. The purified bovine NF-L mixture was preincubated with PLC- $\gamma 1$ at $4^{\circ} \mathrm{C}$ for $1 \mathrm{~h}$, and then $\left[{ }^{3} \mathrm{H}\right] \mathrm{PI}(4,5) \mathrm{P}_{2}$ hydrolyzing activity was measured. As shown in Figure 6, bovine NF-L slightly decreased PLC- $\gamma 1$ activity, while purified BSA (control) did not. Moreover, GST-NF-L(H) also showed the inhibiting effect, and this inhibition probably caused by direct binding with $\mathrm{PLC}-\gamma 1 \mathrm{PH} 1$ domain.

\section{Discussion}

Our present study demonstrates that NF-L interacts with the PH domain of PLC- $\gamma 1$ to inhibit PLC- $\gamma 1$ activity. The PH domains of PLC- $\gamma 1$ have been shown to facilitate membrane targeting via interactions with phosphoinositide (Falasca et al., 1998; Kim et al., 2004) and activate enzymatic activity via protein-protein interactions (Chang et al., 2002). Previously, the amino terminal half of the split $\mathrm{PH}$ domain $(\mathrm{nPH} 2)$ of $\mathrm{PLC}-\gamma 1$ was shown to specifically bind EF-1 $\alpha$ (Chang et al., 2002), the $\beta \gamma$-subunit of small G-protein (G $\beta \gamma$ ) (Thodeti et al., 2000) and $\beta$-tubulin (Chang et al., 2005).

In our previous studies focused on $\beta$-tubulin/PLC$\gamma 1$ interaction (Chang et al., 2005), we unexpectedly found a $68-\mathrm{kDa}$ protein that specifically interacts with $\mathrm{PLC}-\gamma 1 \mathrm{PH} 1$ domain (Figure $1 \mathrm{~A}$ ) from bovine brain tubulin fraction and subsequently from NGF-treated PC12 cell extracts. In this study, we identified and

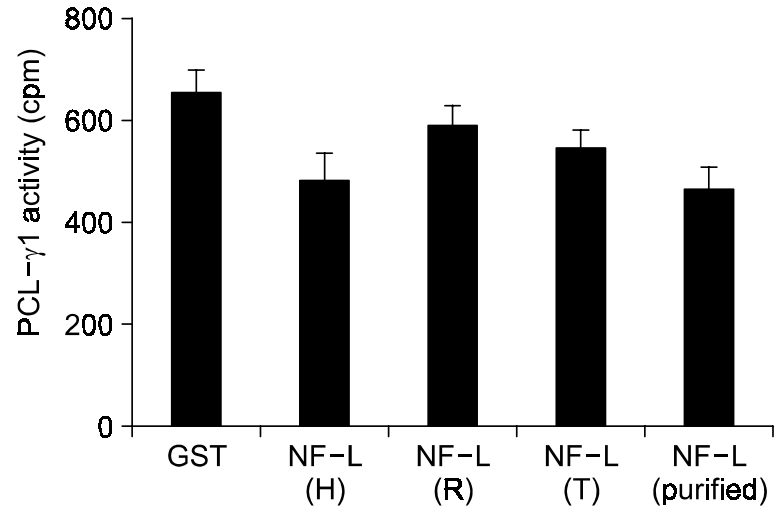

Figure 6. Purified NF-L inhibits PLC- $y 1$ activity. The $\mathrm{PI}(4,5) \mathrm{P}_{2}$ hydrolyzing activity of PLC- $y 1$ was measured in the presence of purified NF-L. The reactions were performed under the conditions of a 1:2 molar ratio (PLC- $y 1$ to NF-L). The PLC- $y 1$ and NF-L proteins used in this experiment were purified from insect sf9 cells and bovine spinal cord, respectively. GST-NF-L fusion proteins were prepared as described in "Experimental Procedures" PLC- $y 1$ activity is expressed as the radioactivity of $\left.{ }^{3} \mathrm{H}\right] \mathbb{I P}_{3}$. The data represent the average of duplicate determinations (mean \pm range) from three experiments with similar results.

characterized the $68-\mathrm{kDa}$ protein as NF-L as a $\mathrm{PLC}-\gamma 1 \mathrm{PH} 1$ domain-associated protein.

We sought the biological relevancy of the PLC$\gamma 1 / \mathrm{NF}-\mathrm{L}$ interaction by examination of the $\mathrm{PI}(4,5) \mathrm{P}_{2}$ hydrolyzing activity of PLC- $\gamma 1$ in the presence or absence of NF-L. In the presence of NF-L (Figure 6), the $\mathrm{PI}(4,5) \mathrm{P}_{2}$ hydrolyzing activity of $\mathrm{PLC}-\gamma 1$ was decreased about $20 \%$. We examined PLC- $\gamma 1$ activity with different concentrations of NF-L, and the lowest activity was shown under the conditions of a 1:2 molar ratio (PLC- $\gamma 1$ to NF-L). Although we did not directly investigate the mechanism for PLC- $\gamma 1$ inactivation, we speculate that NF-L may sequester the phosphoinositides including $\mathrm{PI}(4,5) \mathrm{P}_{2}$ from the $\mathrm{PH}$ domain of PLC- $\gamma 1$. This means that PLC- $\gamma 1$ activity is not required for NF assembly, and suggests that binding of PH domain of PLC- $\gamma 1$ to the head domain of NF-L may preclude NF assembly. This hypothesis is consistent with our previous finding that overexpression of either PLC- $\gamma 1$ or its truncated molecule consisting of $\mathrm{SH} 2-\mathrm{SH} 2-\mathrm{SH} 3$, which contains a split $\mathrm{PH}$ domain $\left(\mathrm{PH}_{2}\right)$, prevented PC12 cell differentiation upon NGF treatment (Bae et al., 1998). Taken together with our previous finding that $\beta$-tubulin promotes PLC- $\gamma 1$ activity (Chang et al., 2005), we propose that cytoskeletal proteins regulate PLC- $\gamma 1$ activity, i.e. that PLC- $\gamma 1$ activity is regulated by NF (a negative) and MT (a positive regulation)

We then sought to determine whether phosphoinositides affects PLC- $\gamma 1 /$ NF-L interactions. In the pre- 
sence of phosphoinositides, NF-L binding affinity for $\mathrm{PH}$ domain of PLC- $\gamma 1$ was substantially increased (Figure 5), suggesting that the PH domain of PLC- $\gamma 1$ may act for adaptor protein for neurofilament transport from cell body to the terminal in nerve cells. Two models have been suggested to account for neurofilament transport: i) neurofilament proteins are assembled in the cell body and transported into axons as fully assembled neurofilaments during axonal outgrowth (Baas and Brown, 1997) and ii) neurofilament proteins move as subunits (monomers or oligomers) and interact with previously assembled neurofilaments to form stable networks in the axon (Hirokawa et al., 1997). In either case, membranelocalized phosphoinositides including $\mathrm{PI}(4,5) \mathrm{P}_{2}$ may act as a terminal-anchor for transporting the neurofilament/PLC- $\gamma 1$ complex, which has been formed in the cell body. This process might resemble the "cargo" model of UNC-104 (KIF1A) transport in Caenorhabditis elegans (Klopfenstein et al., 2002; Klopfenstein and Vale, 2004). This model suggests that the amino-terminal PH domain of PLC- $\gamma 1$ regulates neurofilament transport, and is involved in neuronal differentiation along with phosphoinositides. Although future work will be required to determine the precise mechanism of PLC- $\gamma 1$-mediated $N F-L$ transport and assembly, it is possible that the $\mathrm{PH}$ domain of PLC- $\gamma 1$ may recruit NF-L to the terminal.

In summary, our present results demonstrate that the $\mathrm{PH}$ domain of PLC- $\gamma 1$ directly associates with $N F-L$ to regulate cell differentiation. NF-L is associated with PLC- $\gamma 1$ mainly in the cell body of PC12 cells, where PLC- $\gamma 1$ is inactivated by NF-L.

\section{Acknowledgment}

This work was supported by grants from the Korea Research Foundation (2003-015-C00458).

\section{References}

Al-Chalabi A, Miller CC. Neurofilaments and neurological disease. Bioassays 2003;25:346-55

Baas PW, Brown A. Slow axonal transport: the polymer transport model. Trends Cell Biol 1997;7:380-4

Bae SS, Lee YH, Chang JS, Galadari SH, Kim YS, Ryu SH, Suh PG. Src homology domains of phospholipase C- $\gamma 1$ inhibit nerve growth factor-induced differentiation of PC12 cells. J Neurochem 1998;71:178-85

Berridge MJ. Inositol trisphosphate and calcium signalling. Nature 1993;361:315-25

Chang JS, Seok H, Kwon TK, Min DS, Ahn BH, Lee YH, Suh JW, Kim JW, Iwashita S, Omori A, Ichinose S, Numata O, Seo
JK, Oh YS, Suh PG. Interaction of elongation factor- $1 \alpha$ and pleckstrin homology domain of phospholipase $\mathrm{C}-\gamma 1$ with activating its activity. J Biol Chem 2002; 277:19697-702

Chang JS, Kim SK, Kwon TK, Bae SS, Min DS, Lee YH, Kim SO, Seo JK, Choi JH, Suh PG. Pleckstrin homology domains of phospholipase $\mathrm{C}-\gamma 1$ directly interact with $\beta$ - tubulin for activation of phospholipase $C-\gamma 1$ and reciprocal modulation of $\beta$-tubulin function in microtubule assembly. J Biol Chem 2005;280:6897-905

Ching GY, Liem RK. Assembly of type IV neuronal intermediate filaments in nonneuronal cells in the absence of preexisting cytoplasmic intermediate filaments. J Cell Biol 1993;122: 1323-35

Collard JF, Cote F, Jullien JP. Defective axonal transport in a transgenic mouse model of amyotrophic lateral sclerosis. Nature 1995;375:61-4

Cote F, Collad JF, Julien JP. Progressive neuropathy in transgenic mice expressing the human neurofilament heavy gene: a mouse model of amyotrophic lateral sclerosis. Cell 1993; 73:35-46

Fabrizini GM, Cavallaro T, Angiari C, Bertolasi L, Cabrini I, Ferrarini M, Rizzuto N. Giant axon and neurofilament accumulation in Charcot-Marie-Tooth disease type 2E. Neurology 2004;62:1429-31

Falasca M, Logan SK, Lehto VP, Baccante G, Lemmon MA, Schlessinger J. Activation of phospholipase $C \gamma$ by PI 3-kinase-induced $\mathrm{PH}$ domain-mediated membrane targeting. EMBO J 1998;17:414-22

Flynn G, Purich DL. GTP regeneration influences interactions of microtubules, neurofilaments, and microtubule- associated proteins in vitro. J Biol Chem 1987;262:15443-7

Fuchs E, Weber K. Intermediate filaments: structure, dynamics, function, and disease. Annu Rev Biochem 1994; 63:345-82

Gibson TJ, Hyvonen M, Musacchio A, Saraste M, Birney E. PH domain: the first anniversary. Trends in Biochemical Sciences 1994;19:349-53

Hepler JR, Kozasa T, Smrcka AV, Simon MI, Rhee SG, Sternweis PC, Gilman AG. Purification from Sf9 cells and characterization of recombinant $\mathrm{Gq} \alpha$ and $\mathrm{G} 11 \alpha$. Activation of purified phospholipase $\mathrm{C}$ isozymes by $\mathrm{G} \alpha$ subunits. J Biol Chem 1993;268:14367-75

Hirano A, Donnenfeld H, Sasaki S, Nakano I. Fine structural observations of neurofilamentous changes in amyotrophic lateral sclerosis. J Neuropath Exp Neurol 1984;43: 461-70

Hirokawa N. Cross-linker system between neurofilaments, microtubules, and membranous organelles in frog axons revealed by the quick-freeze, deep-etching method. J Cell Biol 1982;94:129-42

Hirokawa N, Terada S, Funakoshi T, Takeda S. Slow axonal transport: the subunit transport model. Trends Cell Biol 1997;7:384-8

Hisanaga S, Hirokawa N. Molecular architecture of the neurofilament. II. Reassembly process of neurofilament $L$ protein in vitro. J Mol Biol 1990;211:871-82 
Kim SK, Wee SM, Chang JS, Kwon TK, Min DS, Lee YH, Suh PG. Point mutations in the split PLC- $\gamma 1 \mathrm{PH}$ domain modulate phosphoinositide binding. J Biochem Mol Biol 2004;37:720-5

Klopfenstein DR, Tomishige M, Stuurman N, Vale RD. Role of phosphatidylinositol $(4,5)$ bisphosphate organization in membrane transport by the Unc104 kinesin motor. Cell 2002;109:347-58

Klopfenstein DR, Vale RD. The lipid binding pleckstrin homology domain in UNC-104 kinesin is necessary for synaptic vesicle transport in Caenorhabditis elegans. Mol Biol Cell 2004;15:3729-39

Lee MK, Xu Z, Wong PC, Cleveland DW. Neurofilaments are obligate heteropolymers in vivo. Journal of Cell Biology 1993;122:1337-50

Lemmon MA, Ferguson KM, Schlessinger J. PH domains: diverse sequences with a common fold recruit signaling molecules to the cell surface. Cell 1996;85:621-4

Lemmon MA, Ferguson KM. Signal-dependent membrane targeting by pleckstrin homology $(\mathrm{PH})$ domains. Biochemical J 2000;350:1-18

Nakagawa T, Chen J, Zhang Z, Kanai Y, Hirokawa N. Two distinct functions of the carboxyl-terminal tail domain of NF-M upon neurofilament assembly: cross-bridge formation and longitudinal elongation of filaments. J Cell Biol 1995; 129:411-29
Nishizuka Y. Protein kinase $C$ and lipid signaling for sustained cellular responses. FASEB J 1995;9:484-96

Norgren N, Rosengren L, Stigbrand T. Elevated neurofilament levels in neurological diseases. Brain Res 2003; 987:25-31

Shepherd CE, McCann H, Thiel E, Halliday GM. Neurofilament-immunoreactive neurons in Alzheimer's disease and dementia with Lewy bodies. Neurobiol Dis 2002;9: 249-57

Suh PG, Ryu SH, Moon KH, Suh HW, Rhee SG. Inositol phospholipid-specific phospholipase C: complete CDNA and protein sequences and sequence homology to tyrosine kinase-related oncogene products. Proc Natl Acad Sci USA 1988; 85:5419-23

Thodeti CK, Adolfsson J, Juhas M, Sjolander A. Leukotriene $D(4)$ triggers an association between $g \beta \gamma$ subunits and phospholipase C- $\gamma 1$ in intestinal epithelial cells. J Biol Chem 2000;275:9849-53

Watson DF, Nachtman FN, Kuncl RW, Griffin JW. Altered neurofilament phosphorylation and beta tubulin isotypes in Charcot-Marie-Tooth disease type 1. Neurology 1994;44: 2383-7

Xu ZS, Cork L, Griffin JW, Cleveland DW. Increased expression of neurofilament subunit NF-L produces morphological alterations that resemble the pathology of human motor neuron disease. Cell 1993;73:23-33 